\title{
Effect of Environmental Heat on the Performance of Female Farm Workers for Agriculture Operation
}

\author{
Vinita Kashyap $^{1 *}$, A.K. Mehta', Anupam Amitabh' ${ }^{2}$ and Jyotirmay Mahapatra' \\ ${ }^{1}$ Department of Farm Machinery and Power Engineering, College of Technology and \\ Engineering, MPUAT, Udaipur, India \\ ${ }^{2}$ ICAR-Central Institute of Agricultural Engineering, Bhopal, India \\ *Corresponding author
}

\section{A B S T R A C T}

\begin{tabular}{|l|}
\hline K e y w or d s \\
WBGT, Oral \\
temperature, Mean \\
skin temperature, \\
Heart rate, Overall \\
discomfort rate, \\
Heat stress. \\
\hline Article Info \\
\hline $\begin{array}{l}\text { Accepted: } \\
\text { 26 October } 2017 \\
\text { Available Online: } \\
\text { 10 December } 2017\end{array}$ \\
\hline
\end{tabular}

The experiment was conducted at instructional Farm, CTAE, Udaipur. The experiment was conducted during the agricultural operation of wheat harvesting. Ten female farm workers were identified from the workers population in the age group of 20 to 40 years. The experiment was designed for three WBGT conditions i.e. 28,29 and $30^{\circ} \mathrm{C}$ which falls under the heat stress category as per ACGIH norms. Since it is very difficult to achieve exact WBGT condition in the field, therefore a variation of $\pm 0.5^{\circ} \mathrm{C}$ was assumed in the open field conditions. During the experiment oral temperature, mean skin temperature, heart rate and overall discomfort rate were measured. The increase in resting oral temperature was observed from $36.67^{\circ} \mathrm{C}$ to $36.75^{\circ} \mathrm{C}$ whereas increase in working oral temperature was observed from $37.11^{\circ} \mathrm{C}$ to $37.26^{\circ} \mathrm{C}$ with the increase in WBGT. Increase in resting mean skin temperature from $29.25^{\circ} \mathrm{C}$ to $30.39^{\circ} \mathrm{C}$ whereas increase in working mean skin temperature was observed from $32.85^{\circ} \mathrm{C}$ to $34.55^{\circ} \mathrm{C}$ with the increase in WBGT. Increase in resting heart rate was observed from 76 to 81 beats/min whereas increase in working heart rate was observed from 92 to 102 beats/min with the increase in WBGT. Increase in resting ODR was observed from 1.5 to 1.8 whereas increase in working ODR was observed from 4.9 to 6.7 with the increase in WBGT.

\section{Introduction}

The climate of India comprises a wide range of weather conditions across a vast geographic scale and varied topography. The nation has four seasons: winter (December, January and February), summer (March, April and May), a monsoon rainy season (June to September), and a post-monsoon period (October to November). The hottest of all seasons, summer extends in Rajasthan from April to June. During summers, the temperature in Rajasthan is very high and it ranges somewhere between 32 degree Celsius and 46 degree Celsius. The place has an average temperature of 38 degree Celsius. At Udaipur maximum temperature in April varies from 34.5 to $41.1^{\circ} \mathrm{C}$, in May it varies from 35 to $43.2^{\circ} \mathrm{C}$ and in June it varies from 41.9 to $45.9^{\circ} \mathrm{C}$. During these times WBGT outdoor varies from $28^{\circ} \mathrm{C}$ to $32^{\circ} \mathrm{C}$, which is the indication of heat stress according to ACGIH norms. Heat stress may be defined as the combination of all those factors both climatic and non-climatic which lead to convective or radiant heat gains by the body 
or prevent heat dissipation from body. Heat stress occurs when the body's means of controlling its internal temperature starts to fail. As well as air temperature, factors such as work rate, humidity and clothing worn while working may lead to heat stress. Therefore, either it may not be obvious to someone passing through the workplace that there is a risk of heat stress or there should be taken some protective measures for protection against heat stress. Increased heart rate, increased body-core temperature and sweating are the physiological responses to heat stress (Huguette and Pierre, 2009). A significant drop in mental performance is observed at temperatures above $32.2^{\circ}$ (Basic Effective Temperature) in a hot-humid environment and $33^{\circ}$ in a hot-dry environment (Sharma et al., 1983).

Most of the agricultural operations in the country are still being performed by human whether as manual labour or as operator. Ploughing, sowing, intercultural operations and harvesting are the main agricultural operations which are being performed in hot sunny days and some of them are performed by manual tools. Women play a significant and crucial role in agricultural development and allied fields including in the main crop production, livestock production, horticulture, post-harvest operations, agro social forestry, fisheries, etc. Agriculture sector employs $4 / 5$ th of all economically active women in the country. 48percent of India's self-employed farmers are women. When female farm workers are working under open sun or in hot environment during summer season there may be chances of effect of heat stress like heat stroke, heat exhaustion, heat cramps, heat collapse, heat rashes, heat fatigue or skin problem. The excess body temperature should dissipate to environment by the conduction, convection, radiation and evaporative cooling or sweat cooling. Most adverse effects arise from a failure of the body's cooling mechanisms. In heat stress condition the body temperature may rise and receptors sensitive to change in temperature in the skin, muscle, stomach and other areas of the central nervous system. Therefore, the study was undertaken to investigate the effect of environmental heat on the performance of female farm workers for agriculture operation.

\section{Materials and Methods}

Harvesting of wheat was selected for this study as it was performed in the month of $27^{\text {th }}$ March to $15^{\text {th }}$ April at Instructional Farm, CTAE, Udaipur. The temperature is at peak with very low humidity. Generally at Udaipur temperature ranges between $34.5^{\circ} \mathrm{C}$ to $41.1^{\circ} \mathrm{C}$ approximately, which causes high heat stress conditions. The study was conducted on 10 female farm workers. During the study period all the operations for the study were performed by these 10 female farm workers. Selected subjects are having agriculture as their main source of livelihood. All the subjects selected haven't the habits of chewing tobacco and taking any type of liquor. Subjects are between 20 - 40 years of age. The harvesting operation was performed in morning and evening shifts. In morning, the time of operation was kept from 9 AM to $1 \mathrm{PM}$ and in evening from $2 \mathrm{PM}$ to $5 \mathrm{PM}$. For the assessment of effect of environmental heat on the performance of female farm workers, three WBGT (wet bulb globe temperature) conditions as independent parameters were selected i.e. 28,29 and $30^{\circ}$ C.All the female farm workers were asked to perform the harvesting operation continuously for 30 minutes and then allowed to take rest for 10 minutes.

Four dependent parameters including two thermal i.e. oral temperature and mean skin temperature, one physiological i.e. heart rate and one physical parameter i.e. overall discomfort rating were selected for the study. 
The mean skin temperature was measured at three different places on the body (Liu et al., 2011) i.e. anterior calf; left chest and left forearm temperature were selected. Liu et al., 2011, worked on "Evaluation of calculation methods of mean skin temperature for use in thermal comfort study" and they gave formula for the calculation of mean skin temperature up to 15 sites of the body. They found that the calculation method of mean skin temperature with 10 sites was the most appropriate one, due to its high reliability, excellent sensitivity but it was very difficult to measure temperature of 10 sites of the body at a time in open field condition at certain WBGT condition and limited time. So, the formula for three sites of the body for the calculation of mean skin temperature was selected, so that the temperatures of chosen sites could be measure easily.

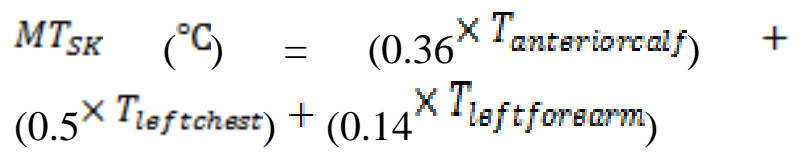

Where,

$M T_{S K}=$ Mean skin temperature, ${ }^{\circ} \mathrm{C}$

$T_{\text {anteriorcalf }}=$ Anterior calf temperature, ${ }^{\circ} \mathrm{C}$

$T_{\text {leftchest }}=$ Left chest temperature, ${ }^{\circ} \mathrm{C}$

$T_{\text {leftforearm }}=$ Left forearm temperature, ${ }^{\circ} \mathrm{C}$

Heat Stress Monitor offers high quality heat stress monitoring without the hassle of wetbulb maintenance.

This model measures/calculates the dry bulb, wet bulb and globe temperatures along with WBGT indoors, WBGT outdoors, relative humidity and Heat Index. Different WBGT of $28^{\circ} \mathrm{C}, 29^{\circ} \mathrm{C}$ and $30^{\circ} \mathrm{C}$ were selected for this study. An infrared non-contact thermometer was used to measure the anterior calf, left chest and left forearm temperature, whereas the doctor's thermometer was used to measure oral temperature of the female farm workers. Polar heart rate monitor was used to measure the heart rate in beats/min and Overall discomfort rating was measured by using a 10-point psycho-physical rating scale developed by Borg (1990). A scale of $70 \mathrm{~cm}$ length was fabricated having 0 to 10 digits marks on it equidistantly. All the measurements were taken during harvesting operation of wheat crop.

\section{Results and Discussion}

Effects of environmental heat on the performance of female farm workers for agriculture operation were assessed for harvesting operation of wheat. Wet Bulb Globe Temperature (WBGT) was recorded with the Quest Temp 36 Heat stress monitor. Clear sky duration was selected in the last week of March to April to meet the required heat stress. Work was started at 09:00 AM to 01:00 PM and then 02:00 PM to 05:00 PM and the selected parameters were measured after 30 minutes of continuous operation.

\section{Effect of WBGT on oral temperature}

Mean values of oral temperature during rest and work is shown in table 1. As shown in table 1 mean value of resting Oral temperature increases with the increase in WBGT, it was lowest $36.67^{\circ} \mathrm{C}$ at $28^{\circ} \mathrm{C}$ WBGT and was highest $36.75^{\circ} \mathrm{C}$ at $30^{\circ} \mathrm{C}$ WBGT. Mean value of working oral temperature increases with the increase in WBGT, it was lowest $37.11^{\circ} \mathrm{C}$ at $28^{\circ} \mathrm{C}$ WBGT and was highest $37.26^{\circ} \mathrm{C}$ at $30^{\circ} \mathrm{C}$ WBGT, similarly Majid et al., (2006) found that oral temperature in working condition increases with increase in WBGT due to heat stress and according to oral temperature criteria, 16.25 percent of exposed population had readings over $37.5^{\circ} \mathrm{C}$ and were under heat stress. Dharaiya (2015) found that oral temperature varied from $35.75^{\circ} \mathrm{C}$ at WBGT 
$24^{\circ} \mathrm{C}$ to $37.22^{\circ} \mathrm{C}$ at WBGT of $28^{\circ} \mathrm{C}$ i.e. oral temperature increases with increase in WBGT during working condition and Singh (2013) also found that increase oral temperature was from $36.72^{\circ} \mathrm{C}$ at WBGT $28^{\circ} \mathrm{C}$ to $38.24^{\circ} \mathrm{C}$ at WBGT $30^{\circ} \mathrm{C}$ with the increase in WBGT (Fig. 1).

\section{Effect of WBGT on mean skin temperature}

Mean values of mean skin temperature is shown in table 2 which is calculated by the formula of mean skin temperature as mentioned in section 2 by measuring the anterior calf, left chest and left forearm temperature. As shown in table 2 mean value of resting mean skin temperature increases with the increase in WBGT, it was lowest $29.25^{\circ} \mathrm{C}$ at $28^{\circ} \mathrm{C}$ WBGT and was highest $30.39^{\circ} \mathrm{C}$ at $30^{\circ} \mathrm{C}$ WBGT. As shown in table 2 mean value of working mean skin temperature increases with the increase in WBGT, it was lowest $32.85^{\circ} \mathrm{C}$ at $28^{\circ} \mathrm{C}$ WBGT and was highest $34.55^{\circ} \mathrm{C}$ at $30^{\circ} \mathrm{C}$ WBGT, nearly similar result was also found by Yao et al., (2007) i.e. mean skin temperature increases with increase in ambient temperature (Fig. 2).

\section{Effect of WBGT on physiological responses}

Experiments were conducted to assess the effect of environmental heat on the physiological responses. Effect of WBGT on Heart Rate (Resting, Working) during the harvesting operation in Rabi season was measured. Resting heart rate and working heart rate of the ten subjects were measured at different WBGT. Mean value table of Heart rates with WBGT is given below in table 3 .

It can be seen that Resting HR varied from 76 beats/min at WBGT of $28^{\circ} \mathrm{C}$ to 81 beats/min at WBGT of $30^{\circ} \mathrm{C}$. Working HR varied from 92 beats/min at WBGT of $28^{\circ} \mathrm{C}$ to 102 beats/min at $\mathrm{WBGT}$ of $28^{\circ} \mathrm{C}$. In figure 3 , resting and working heart rates were observed to increase with increase in WBGT. This increase was due to heat stress which was induced due to increase in WBGT whereas Majid et al., (2006) also found that heart increases with increase in WBGT. Dhairya (2015) found that resting heart rate increases from 71 beats/min at WBGT $24^{\circ} \mathrm{C}$ to 87 beats/min at WBGT $28^{\circ} \mathrm{C}$ and working heart rate increases from 75 beats $/ \mathrm{min}$ at $24^{\circ} \mathrm{C}$ and highest 101 beats/min at $28^{\circ} \mathrm{C}$. Singh (2013) found physiological parameters like resting and working heart rate as well as resting increased with increase in WBGT. Huguette and Pierre (2009) also found that working heart rate increases with increase in WBGT.

\section{Effect of WBGT on physical discomfort}

To assess the effect of environmental heat i.e. WBGT on physical discomfort overall discomfort rate (ODR) was measured. It can be seen that overall discomfort rate varies from 1.5 at $28{ }^{\circ} \mathrm{C}$ to 1.8 at $30^{\circ} \mathrm{C}$ during rest whereas 4.9 at $28{ }^{\circ} \mathrm{C}$ to 6.7 at $30{ }^{\circ} \mathrm{C}$ during work. Mean values of overall discomfort rate with WBGT are given in the 3.4

In figure 4, Overall Discomfort Rate was observed to increase with increase in WBGT. This increase was due to heat stress which was induced due to increase in WBGT (Table 4).

Similarly Dhairya (2015) found that overall discomfort rate increases from 2.2 at WBGT $24{ }^{\circ} \mathrm{C}$ to 4.9 at WBGT $28{ }^{\circ} \mathrm{C}$. Singh (2013) also found that and Overall Discomfort Rate (ODR) increases with increase in WBGT due to heat stress.

The study conducted on ten female farm farm workers for assessing the effect of environmental heat on performance of female farm workers for agriculture operation and it reveals that WBGT induces heat stress on human body during farm operations. 
Table.1 Mean values of oral temperature at different WBGT in resting condition

\begin{tabular}{cccc}
\hline S. No. & Treatment & Oral Temp. $\left({ }^{\circ} \mathbf{C}\right)$ Rest & Oral Temp. $\left({ }^{\circ} \mathbf{C}\right)$ Work \\
\hline 1 & $28^{\circ} \mathrm{C}$ WBGT & 36.67 & 37.11 \\
2 & $29{ }^{\circ} \mathrm{C}$ WBGT & 36.72 & 37.19 \\
3 & $30^{\circ} \mathrm{C}$ WBGT & 36.75 & 37.26 \\
& Mean & 36.71 & 37.19 \\
\hline
\end{tabular}

Table.2 Mean values of mean skin temperature at different WBGT

\begin{tabular}{cccc}
\hline S. No. & Treatment & $\begin{array}{c}\text { Mean skin temp. during } \\
\text { rest }\left({ }^{\circ} \mathbf{C}\right)\end{array}$ & $\begin{array}{c}\text { Mean skin temp. during } \\
\text { work }\left({ }^{\circ} \mathbf{C}\right)\end{array}$ \\
\hline 1 & $28^{\circ} \mathrm{C}$ WBGT & 29.25 & 32.85 \\
2 & $29^{\circ} \mathrm{C}$ WBGT & 30.05 & 33.21 \\
3 & $30^{\circ} \mathrm{C}$ WBGT & 30.39 & 34.55 \\
& Mean & 29.89 & 33.54 \\
\hline
\end{tabular}

Table.3 Mean values of heart rates with WBGT

\begin{tabular}{cccc}
\hline S. No. & Treatment & Resting HR & Working HR \\
\hline 1 & $28^{\circ} \mathrm{C}$ WBGT & 76 & 92 \\
2 & $29^{\circ} \mathrm{C}$ WBGT & 78 & 96 \\
3 & $30^{\circ} \mathrm{C}$ WBGT & 81 & 102 \\
& Mean & 78 & 97 \\
\hline
\end{tabular}

Table.4 Mean values of overall discomfort rate with WBGT

\begin{tabular}{ccc}
\hline Treatment & Resting ODR & Working ODR \\
\hline $28^{\circ} \mathrm{C}$ WBGT & 1.5 & 4.9 \\
$29^{\circ} \mathrm{C}$ WBGT & 1.6 & 5.8 \\
$30^{\circ} \mathrm{C}$ WBGT & 1.8 & 6.7 \\
Mean & 1.6 & 5.8 \\
\hline
\end{tabular}

Heat Stress Monitor offers high quality heat stress monitoring without the hassle of wetbulb maintenance

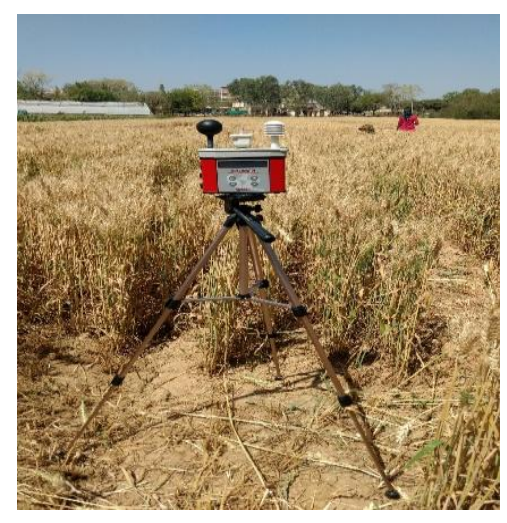


Fig.1 Variation in oral temperature with WBGT

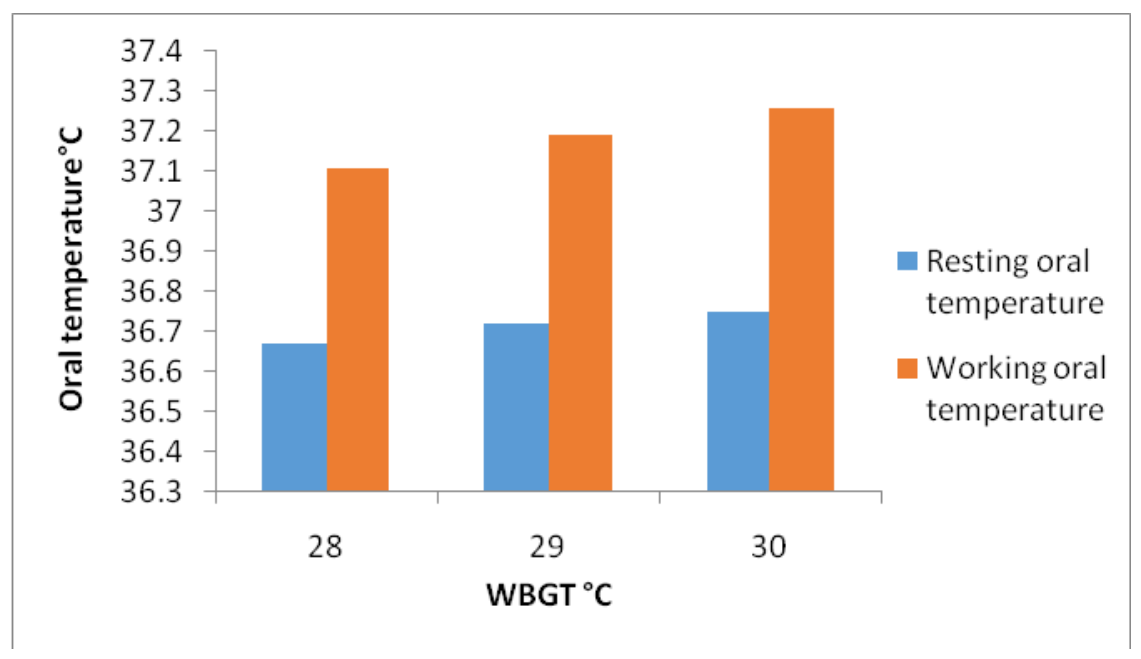

Fig.2 Variation in mean skin temperature with WBGT

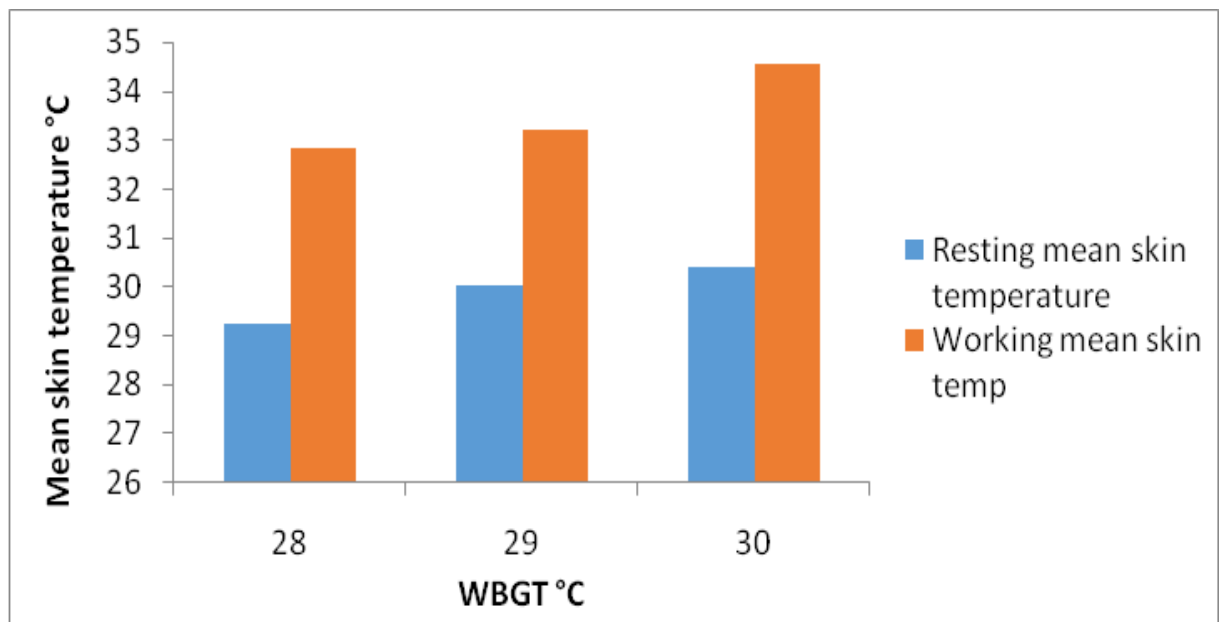

Fig.3 Variation in heart rate with WBGT

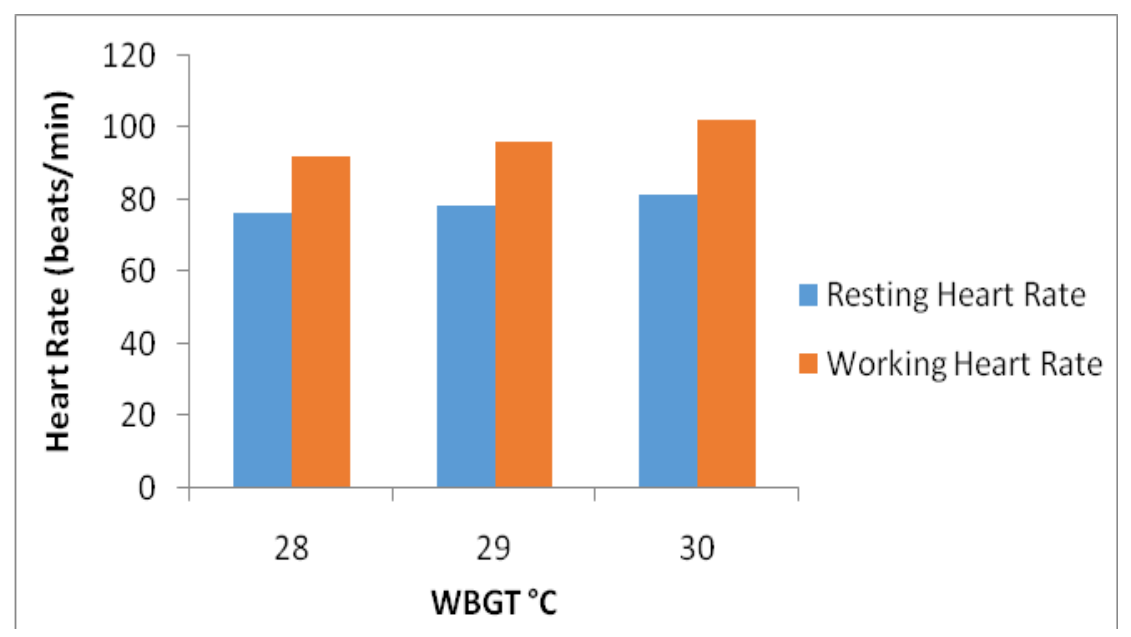


Fig.4 Variation in ODR with WBGT

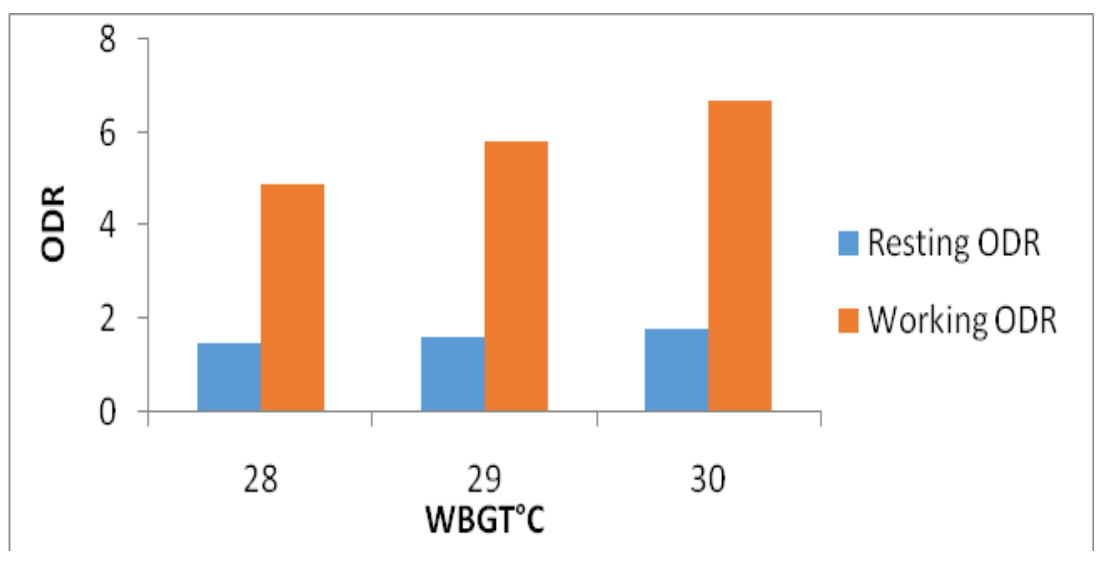

The mean skin temperature and oral temperature of female farm workers increases with the increase in WBGT. Physiological parameters like resting and working heart rate increases with increase in WBGT. Physical discomfort parameter overall discomfort rate (ODR) increases with increase in WBGT due to heat stress.

Following conclusions were drawn from the experiments conducted on the field.

Mean skin temperature increased from $29.25^{\circ} \mathrm{C}$ to $30.39^{\circ} \mathrm{C}$ during rest and from $32.85^{\circ} \mathrm{C}$ to $34.55^{\circ} \mathrm{C}$ during work with the increase in WBGT from 28 to $30^{\circ} \mathrm{C}$ while oral temperature increased from $36.67^{\circ} \mathrm{C}$ to $36.75^{\circ} \mathrm{C}$ during rest and from $37.11^{\circ} \mathrm{C}$ to $37.26^{\circ} \mathrm{C}$ during work during same WBGT condition.

Resting heart rate increased from 76to 81 beats/min and working heart rate from 92 to 102 beats/min with the increase in WBGT from 28 to $30^{\circ} \mathrm{C}$. Overall discomfort rate increased from 1.5 to 1.8 during rest and from 4.9 to 6.7 during work.

In such agricultural operation which are performed in hot sunny days or in high temperature, female farm worker must use different things for body protection.

\section{References}

American Conference of Governmental Industrial Hygienists (ACGIH) 1990, Documentation of the Threshold Limit values for chemical substances and physical agents and biological exposure indices, Cincinnati.

Anonymous, 2011: Monsoon Report 2011 (1st June 2011 to 31 September 2011), Published by Indian Meteorological Department, New Delhi.

Celia, H., Rob, D., Ron, S., Kirsten, B., Judith, H. and Julien, G. 2014.Effect of severe heat stress on immune function, biochemistry and histopathology in farmed Australian abalone. Aquaculture 432: 26-37.

Dharaiya, P. A. 2015. Development and comparative evaluation of headgear for farm worker under the heat stress condition. M. Tech thesis submitted to Maharana Pratap University of Agriculture and Technology, Udaipur, Rajasthan.

Huguette, M. M. L. and Pierre, D. 2009. Physiological responses to heat strain: A study on personal monitoring for young workers. Journal of Thermal Biology 34: 299-305.

Ismail, A. R., Rani, M. R. A., Makhbul, Z. K. M., Nor, M. J. M. and Rahman, M. N. 
A. 2009. A Study of Relationship between WBGT and Relative Humidity to Worker Performance. World Academy of Science, Engineering and Technology 51: 209-214.

Liu, W., Lian, Z., Deng, Q. and Liu, Y. 2011.Evaluation of calculation methods of mean skin temperature for use in thermal comfort study. Building and Environment 46: 478-488.

Majid, M. and Mansour, R. A. 2006.Heat Stress Evaluation Using Environmental and Biological Monitoring. Pakistan Journal of Biological Sciences 9: 457459.

Occupational safety and hazard analysis (OSHA) technical manual, 1992, Chapter-4 Heat stress.

Sharma, V. M., Pichan, G. and Panwar, M. R. 1983. Differential effects of hot-humid and hot-dry environments on mental functions. International Archives of Occupational and Environmental Health 52: 315-327.

Shimazaki, Y., Goto, S., Yoshida, A. and Yamamoto, T. 2017. The effect of solar radiation on temperature distribution in outdoor human clothing environment systems. International Journal of Heat and Mass Transfer 104: 1-6.
Singh, S. K. 2013. Development of work rest cycle for selected farm operations under heat stress for male agricultural workers. Ph.D. thesis submitted to Maharana 29 Pratap University of Agriculture and Technology, Udaipur, Rajasthan.

Sousa, D. J., Cheatham, C. and Wittbrodt, M. 2014. The effects of a moisture-wicking fabric shirt on the physiological and perceptual responses during acute exercise in the heat. Applied ergonomics 45: 1447-1453.

Swamikannan, D. and Jeyalakshmi, C. 2015. Women Labour in Agriculture in India: Some Facets. Women 1.

Williams, W. J., Coca, A., Kim, J. H. and Roberge, R. 2014. Repeatability of physiological responses during two repeated protective clothing performance tests under identical test conditions. International Journal of Industrial Ergonomics 44: 793-799.

Yao, Y., Lian, Z., Liu, W. and Shen, Q. 2008.Experimental study on physiological responses and thermal comfort under various ambient temperatures. Physiology \& Behavior 93: 310-321.

\section{How to cite this article:}

Vinita Kashyap, A.K. Mehta, Anupam Amitabh and Jyotirmay Mahapatra. 2017. Effect of Environmental Heat on the Performance of Female Farm Workers for Agriculture Operation. Int.J.Curr.Microbiol.App.Sci. 6(12): 3295-3302. doi: https://doi.org/10.20546/ijcmas.2017.612.383 